\title{
Penyetaraan tes soal potensi akademik berdasarkan teori respon butir menggunakan Software $R$ di STMIK AKBA
}

\author{
Akbar Iskandar', Ahmad Rudi ${ }^{2}$ \\ ${ }^{1}$ STMIK AKBA, \\ e-mail: akbar.iskandar06@gmail.com \\ ${ }^{2}$ SMA Addaraen Makassar \\ e-mail: ahmadrudi726@gmail.com
}

(Received: Juni-2017; Reviewed: Juli-2017; Revised: Juli-2017; Accepted: Agustus-2017; Published: Agustus-2017)

(7) (8) (C2017-EST Program Pascasarjana Universitas Negeri Makassar. Ini adalah artikel dengan akses terbuka dibawah licenci CC BY-NC-4.0 (https://creativecommons.org/licenses/by-nc/4.0/).

\begin{abstract}
This study aims to determine the quality of the package about the Academic Potential Test, to know the procedure of equalizing the package of test of Academic Potential Test and to know how to get two sets of tests that have equality with the method of testEquatigdata .. The type of research is explorative, which will reveal the equivalence of test scores based on response- Items. Tithe equivalence procedure, horizontal equalizer selection, common item nonequivalent group equalization selection, third parameter estimation using $2 P$ model (different power and difficulty level) and four equalization process using testEquatingData. Results Equivalence tests with the EQuestData method based on the grain response theory using the 2 parameter model, indicating that the average difficulty level on both packages differs from the packet value of 01 (-1.32934) and the packet value 02 (-2.63645). While the difference between the two packages is different and shows that it can not distinguish the ability of the participants, between high ability and low participant ability, based on the value of package 01 (-0.26831) and package 02 (-0.37774).
\end{abstract}

Keywords: Software R, Test Equating, Item Respons Theory.

\begin{abstract}
ABSTRAK
Penelitian ini bertujuan untuk mengetahui kualitas paket soal Tes Potensi Akademik, mengetahui prosedur penyetaraan paket soal Tes Potensi Akademik dan mengetahui cara mendapatkan dua perangkat tes yang memilki kesetaraan dengan metode tesEquatigdata.. Jenis penelitian adalah exploratif, yaitu akan mengungkap kesetaraan skor tes berdasarkan teori respons-butir. Prosedur penyetaraan tes, pemilihan jenis penyetaraan horizontal, pemilihan desain penyetaraan common item nonequivalent group, ketiga estimasi parameter dengan menggunakan model $2 P$ (daya beda dan tingkat kesulitan) dan keempat proses penyetaraan dengan menggunakan testEquatingData. Hasil Penyetaraan tes dengan Metode tesEquatingData berdasarkan teori respon butir menggunakan model 2 parameter, menunjukkan bahwa rata-rata tingkat kesulitan pada kedua paket berbeda dengan nilai paket 01 (-1.32934) dan nilai paket 02 (-2.63645). Sedangkan ditinjau dari daya beda kedua paket juga berbeda dan menunjukkan bahwa tidak dapat membedakan kemampuan peserta, antara kemampuan tinggi dengan kemampuan peserta rendah, berdasarkan nilai paket 01 (-0.26831) dan paket 02 (-0.37774).
\end{abstract}

Kata Kunci: Software R, Penyetaraan Tes, Teori Respon Butir 


\section{PENDAHULUAN}

Sofware R merupakan program aplikasi yang banyak digunakan dalam menganalisis kualitas butir soal baik pada tingkat nasional maupun pada tingkat internasional namun kurang dimanfaatkan oleh sebagian pendidik baik dosen ataupun guru dalam pengambila kebijakan penentuan kualitas soal yang dapat digunakan dalam tes seleksi maupun mengukur potensi akademik yang dimiliki oleh mahasiswa. Sedangkan prestasi akademik dipengaruhi oleh 3 faktor utama, yaitu: konteks, input mahasiswa serta proses perkuliahan.

Salah satu kegiatan yang banyak dilakukan dalam dunia pendidikan adalah melakukan tes untuk menguji kemampuan peserta didik. Apabila hasil tes tersebut dijadikan dasar untuk menentukan 'nasib' peserta ujian (misalnya lulus/tidak lulus, diterima/titolak), maka sudah seharusnya kualitas tes ujian memenuhi syarat sebagaimana yang ditentukan. Beberapa kriteria yang dikelompokkan pendekatan tradisional untuk mengukur kualitas tes diantaranya adalah validitas, reliabilitas, tingkat kesukaran daya beda item soal.

Pendekatan ini walaupun tergolong tradisional, namun masih banyak dipakai untuk menguji perangkat evalusi pembelajaran. Pendekatan yang tergolong modern, salah satunya menggunakan pendekatan logistik disebut dikenal dengan IRT dimana software tersebut berbasis open source, sehingga mudah diakses dan tidak menyalahi peraturan tentang hak cipta. Analisis modern atau lebih dikenal dengan teori respon butir lebih sempurna dalam mengakuisisi hasil analisis. Kelemahan yang ada di teori klasik seperti ketidakmampuan mengestimasi parameter butir dapat diperhatikan lebih lanjut.

Mardapi, (2012:223) menguraikan bahwa ujian merupakan salah satu bentuk asesmen formatif yang tujuannnya untuk mengetahui pencapaian standar pendidikan dan Hasil ujian nasional dapat dijadikan masukan terhadap perbaikan proses pembelajaran di satuan pendidikan serta mendorong pendidik untuk selalu menyempurnakan strategi pembelajaran yang digunakan. Penyempurnaan atau perbaikan ini diharapkan akan meningkatkan prestasi belajar peserta didik baik pada aspek kognitif, psikomotor, dan afektif. Semua aspek ini penting dan harus dinilai untuk mengetahui pencapaiaanya. Tamsyani (2016:11) menambahkan bahwa Kualitas sumber daya manusia merupakan prasyarat bagi kemajuan suatu bangsa khususnya sekolah, sedangkan untuk mendapatkan kualitas SDM yang baik maka harus memiliki instrument tes yang baik pula untuk menyeleksinya.

Selanjutnya Daeng (2015:29) menambahkan bahwa dalam proses belajar mengajar guru harus memegang prinsip yang telah dikeluarkan oleh depdiknas terkait dengan penentuan materi pembelajaran seperti kesesuaian (relevansi), keajegan (konsistensi), dan kecukupan (adequacy). Selanjutnya, dalam penentuan cakupan materi pembelajaran harus pula diperhatikan apakah materi pembelajaran yang disajikan berupa aspek kognitif (fakta, konsep, prinsip, prosedur) aspek afektif, ataukah aspek psikomotor. Selain ketiga prinsip di atas, prinsip lain yang perlu digunakan dalam menentukan cakupan materi pembelajaran adalah keluasan, kedalaman dan, kecukupan materi.

Dalam membuat perangkat tes yang sempurna paralel tidaklah mudah. Masih saja terdapat kekurangan pada masalah keadilan. Bisa jadi, perangkat antara satu dengan yang lainnya memiliki kualitas tes yang berbeda seperti paket 1 lebih mudah atau lebih sulit daripada perangkat tes 2 atau bahkan sebaliknya. Hal tersebut menjadi kendala dalam setiap penilaian ketika hasil ujian menggunakan pilhan ganda dijadikan suatu patokan tertentu untuk mengukur prestasi calon peserta tes.

Inteni, Candiasa, \& Suarni, (2013:9) Penilaian dapat digunakan sebagai salah satu faktor dalam menentukan keberhasilan proses pembelajaran, bukan hanya sebagai cara untuk menilai keberhasilan siswa dalam menguasai materi pembelajaran. Guru sebagai salah satu faktor utama dalam meningkatkan mutu pendidikan harus terampil menilai proses dan hasil belajar peserta didik seperti membuat alatalat penilaian, mengolah data dan hasil penilaian, mendiagnosis kesulitan belajar, serta memanfaatkan hasil penilaian.

Namun yang terjadi sampai saat ini banyak instrumen penilaian hasil belajar, baik yang digunakan oleh untuk ulangan harian maupun yang digunakan dalam seleksi calon mahasiswa baru oleh kampus untuk ujian masuk dan soal ujian nasional yang sudah lama dikenal di Indonesia yang mana belum memenuhi persyaratan ideal. Sementara instrumen penilaian hasil belajar yang mengandung bias butir akan merugikan siswa yang memiliki kemampuan sama dengan siswa yang menjawab benar hanya dikarenakan kelompoknya berbeda. 
Atau dengan kata lain, instrumen yang mengandung bias butir tidak memberi peluang sama untuk menjawab benar pada peserta tes yang memiliki kemampuan sama hanya karena berasal dari kelompok yang berbeda (Mistiani, 2015:284).

Dalam melaksanakan kegiatan evaluasi, berhasil atau tidaknya sangat ditentukan oleh tepat atau tidaknya pelaksanaan ujian. Untuk melaksanakan ujian ini memerlukan alat-alat. Bagi ujian tertulis maka alatnya adalah butirbutir soal tertulis. Bagi ujian lisan maka alatnya adalah butir soal tertulis yang disediakan bagi setiap testi, atau sekurang-kurangnya pokok pertanyaan yang sudah tertulis dan dipersiapkan sebelumnya. Bagi ujian praktek, maka alatnya adalah lembar pengamatan yang berisi segi-segi yang diamati beserta rentang skor masingmasing.

Ruslan (2005:132) dalam evaluasi pembelajaran aspek keadilan merupakan salah satu prinsip yang penting. Artinya, peserta didik yang menghadapi ujian di berbagai wilayah dan waktu yang berbeda mesti mendapat perlakuan yang adil. Mereka mesti diberi kesempatan untuk menjawab butir-butir tes yang memiliki isi (content) dan tingkat kesukaran yang sama. Persoalan akan muncul apabila peserta didik diuji dengan tes yang sama dalam waktu yang berbeda. Seperti yang terjadi pada kelas-kelas parallel, peserta didik yang mengambil ujian pada waktu terakhir akan diuntungkan dengan adanya soal ujian yang bocor sedangkan seleksi pada umumnya dilakukan untuk 2 tujuan, yaitu untuk menyesuaikan jumlah calon mahasiswa dengan tempat yang tersedia dan untuk mendapatkan mahasiswa yang dapat mengikuti program pendidikan yang sulit dengan sukses dan kemudian dapat menjadi anggota profesi yang efektif (Permatasari, Prabandari, \& Kristina, 2016:81).

Dalam pelaksanaan evaluasi yang menggunakan beberapa perangkat tes yang berbeda dan mengukur hal yang sama perlu dilakukan penyetaraan dari beberapa perangkat tes tersebut, karena dengan adanya penyetaraan dapat dijamin keadilan bagi peserta tes". Hambleton \& Swaminathan, 1985 (Bintarawati, 2012:112) “ mengingatkan bahwa sekalipun perangkat tes yang disusun berdasarkan kisi-kisi yang sama, jarang sekali bahkan hampir tidak ditemukan perangkat tes yang benar-benar setara dalam sebaran serta peringkat indeks kesukaran. Dengan demikian, menjadi suatu keharusan bagi pengembang tes atau lembaga pengembang tes untuk melakukan penyetaraan terhadap perangkat tes yang digunakan.

Satu tantangan besar bagi pengembang asesmen pendidikan adalah mengatasi persoalan yaitu bagaimana membandingkan prestasi dan berbagai kelompok peserta tes, berdasarkan tahun ajaran yang berbeda maupun berbagai sekolah yang berbeda. Meskipun teori klasik masih digunakan secara luas dalam pengukuran pendidikan di Indonesia, namun teknik tersebut memiliki keterbatasan yaitu ketika tes-tes yang berbeda diberikan kepada para peserta tes yang berbeda dan hasilnya diungkapkan dengan skor mentah, kemampuan peserta tes tidak dapat dibandingkan berdasarkan pada skor total. Dalam hal ini, yang menjadi persoalan adalah seorang peserta tes yang lebih rendah kemampuannya, mungkin telah mendapatkan skor yang lebih tinggi pada sebuah tes yang mudah, dibandingkan dengan peserta tes lain yang lebih tinggi kemampuannya yang mungkin memperoleh nilai yang lebih rendah pada tes yang lebih sulit. Keadaan ini menggambarkan bahwa skor-skor tersebut tidak dapat diperbandingkan karena dimungkinkan kedua tes tersebut dibuat pada skala yang berbeda. Oleh karena itu perlu disusun tes-tes yang setara, agar supaya skor tes yang diperoleh dapat saling dipertukarkan (Syaifuddin,2005:4).

Pada kebanyakan program tes dalam skala besar, penyusunan tes-tes yang setara merupakan kegiatan yang sangat penting, untuk penanganan yang cepat, apabila terjadi kebocoran tes, dan untuk membandingkan hasil tes dari peserta yang menggunakan tes-tes yang berbeda itu. Hal yang sama juga dialami oleh sekolah sebagai suatu institusi pengelola pendidikan yang senantiasa berurusan dengan program tes, meskipun umumnya tidak dalam skala besar (Tumilisar, 2006:1-2).

Aminah (2012:93) mengungkapkan bahwa terdapat dua cara penyetaraan tes yaitu penyetaraan tes vertical dan horizontal dimana penyetaraan tes vertical adalah suatu usaha untuk menyetarakan skor tes pada dua tes atau lebih yang dirancang berbeda tingkat kesulitan tetapi mengukur isi dan jenis kemampuan yang sama. Penyetaraan vertical dirancang untuk kontinuitas tes. Kontinuitas tes diartikan sebagai keberlanjutan tes yang digunakan untuk mengukur perkembangan atau perubahan tingkat kemampuan siswa. Cara penyetaraan horizontal dilakukan pada tes paralel yang memiliki kesamaan isi dan tingkat kesulitan, kemudian 
diberikan pada kelompok siswa yang memiliki tingkat kemampuan setara.

Jika hasil tes itu digunakan untuk menentukan kenaikan kelas atau penjurusan program, tentunya hal itu menjadi tidak adil karena tidak dilakukan ekivalensi skor untuk tes yang berbeda itu. Masalah tersebut dapat diatasi dengan melakukan penyetaraan skor yang diperoleh dari peserta yang mengambil tes-tes itu dan kesetaraan antarskor dapat dilakukan secara statistic dimana proses statistik, dikenal sebagai metode penyetaraan (equating), telah dikembangkan untuk menangani masalah ini Kolen \& Brennan, 1995 (Antara \& Bastari, 2015:15).

Penyetaraan tes sangat dirasakan kegunaan mengingat mutu pendidikan di Indonesia belum merata dan keadaan geografis Indonesia sebagai negara kepulauan yang cukup luas. Hal ini mengakibatkan pengukuran secara serentak dalam waktu yang sama tidak mudah dilakukan. Adanya kebijaksanaan otonomi pendidikan pelaksanaan pendidikan sudah menjadi wewenang daerah setempat, namun pemerintah pusat tetap berkewajiban untuk mengendalikan kualitas pendidikan nasional. Misalnya, dengan penetapan kurikulum nasional dan kemampuan standar pada tingkat tertentu. Pengendalian akan mudah dilakukan jika perangkat tes di tiap-tiap daerah diketahui tingkat kesetaraan. Tingkat kesetaraan perangkat tes yang berbeda akan dapat diketahui melalui proses penyetaraan (Miyatun \& Mardapi, 2000 :2-3).

Berdasarkan uraian di atas, memberikan gambaran bahwa penyetaraan tes sebagai salah satu upaya pengembangan alat ukur dalam mengevaluasi hasil belajar siswa perlu dikembangkan dalam berbagai bidang ilmu, terutama pada tingkat pendidikan dasar dan menengah hingga perguruan tinggi. Menurut Aminah (2012:92) "Penyetaraan skor adalah membandingkan skor yang diperoleh dari perangkat tes yang satu (X) dan perangkat tes lainnya (Y) yang dilakukan melalui proses penyetaraan skor pada kedua perangkat tes tersebut.serta dapat digunakan untuk mengatur skor pada format-format tes sehingga skor pada format tersebut dapat diperbandingkan.

Mensetarakan perangkat-perangkat tes yaitu mengkonversikan sistem unit-unit sesuatu perangkat ke sistem unit-unit perangkat yang lain, sehingga skor-skor yang dijabarkan dari dua perangkat tes setelah konversi seacar langsung akan setara. Jika penyetaraan itu dilakukan dengan baik, maka akan mungkin menyatakan bahwa terjadi penurunan atau peningkatan rata-rata kelompok. Dengan proses pensetaraan yang benar-benar memenuhi persyaratan, maka selanjutnya orang akan dapat mengukur perkembangan, memetakan kecenderungan-kecenderungan,

menggabungkan data atau informasi yang berasal dari perangkat-perangkat-perangkat tes yang berbeda.

Penyetaraan bukan untuk memprediksi skor pada salah satu tes ke skor tes yang lain, melainkan untuk perbandingan antara skor yang disetarakan. Tujuan penyetaraan adalah untuk menghasilkan skor yang ekuivalen yang berasal dari dua atau lebih perangkat tes. "Pada dasarnya penyetaraan (equating) bertujuan untuk menyetarakan skor dengan cara membandingkan skor yang diperoleh dari mengerjakan perangkat tes yang satu dengan skor yang diperoleh dari mengerjakan perangkat tes lainnya yang dilakukan melalui proses penyetaraan skor pada kedua perangkat tes tersebut". Jadi, Melalui penyetaraan penyetaraan dapat diperoleh skor yang dapat diperbandingkan.

Berdasarkan beberapa pendapat tentang penyetaraan tes, dapat dikatakan bahwa penyetaraan atau equating merupakan suatu prosedur dalam membandingkan perangkat tes yang satu $(\mathrm{X})$ ke perangkat tes yang lain $(\mathrm{Y})$, sehingga hasil-hasilnya dapat diperbandingkan atau dipertukarkan penggunaannya.

\section{METODE}

Jenis penelitian ini adalah penelitian yang bersifat exploratif, yaitu mencari, mengungkap, menggali secara cermat dan lengkap fakta-fakta yang terkandung dalam suatu permasalahan yang bersifat spesifik. Dalam penelitian ini, peneliti mengungkap karakteristik soal TPA tahun ajaran 2016-2017 model 2 parameter, kesetaraan tes dengan metode tesEquating Data. Penelitian dilaksanakan di STMIK AKBA. Subjek dalam penelitian ini adalah butir soal dan seluruh lembar jawaban peserta tes. Desain penyetaraan yang digunakan adalah desain common item nonequivalent groups. Pengumpulan data dalam penelitian ini dilakukan dengan menggunakan teknik dokumentasi. Teknik Analisis Data (1) Proses Validasi Isi, 2. (2) pengumpulan data dengan menggunakan desain common item nonequivalent group. (3) Estimasi parameter butir dengan analisis $R$ Program V.3.2.0 


\section{HASIL DAN PEMBAHASAN}

\section{Hasil}

\section{a. Tingkat Kesulitan Paket 01 dan 02}

Gambar 1. Kurva Karakteristik Butir Soal Paket 01 Model 2P Berdasarkan Tingkat Kesulitan

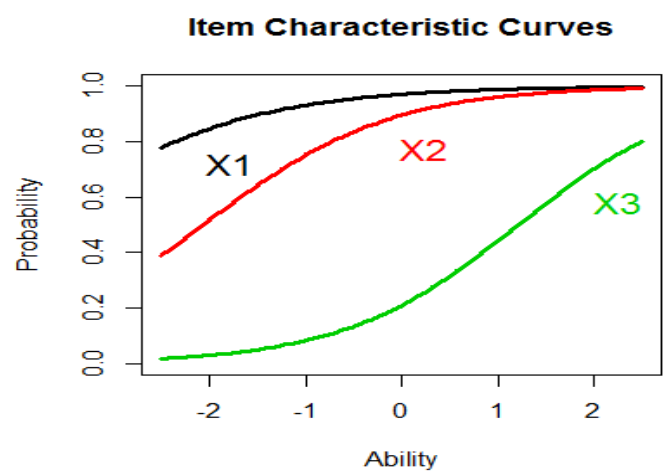

Gambar 1. Menunjukkan bahwa dari Paket 01 untuk butir 1, 2 dan 3 berada pada ketegori sukar dan sangat sukar. Berdasarkan grafik di atas butir 3 dengan koefisien $(3,220)$, butir 2 ($2,057)$ dan butir $1(-3,913)$.

Gambar 2. Kurva Karakteristik Butir Soal Paket 02 Model 2P Berdasarkan Tingkat Kesulitan

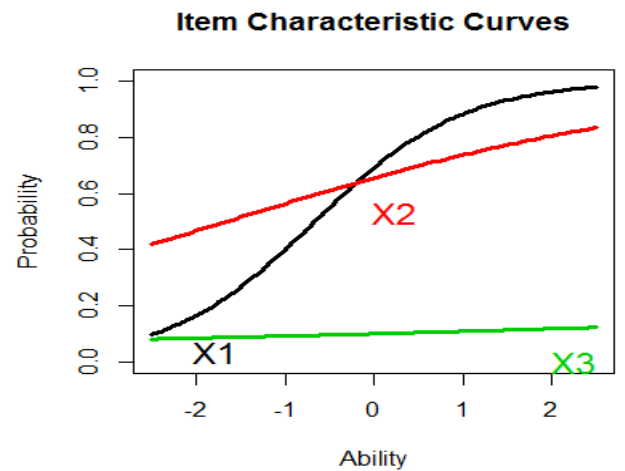

Gambar 2. Menunjukkan bahwa dari Paket 01 untuk butir 1, 2 dan 3 berada pada ketegori sukar dan sangat sukar. Berdasarkan grafik di atas butir 3 dengan koefisien $(23,787)$, butir 2 ($1,648)$ dan butir $1(-0,661)$.

\section{b. Daya Beda Paket 01 dan Paket 02}

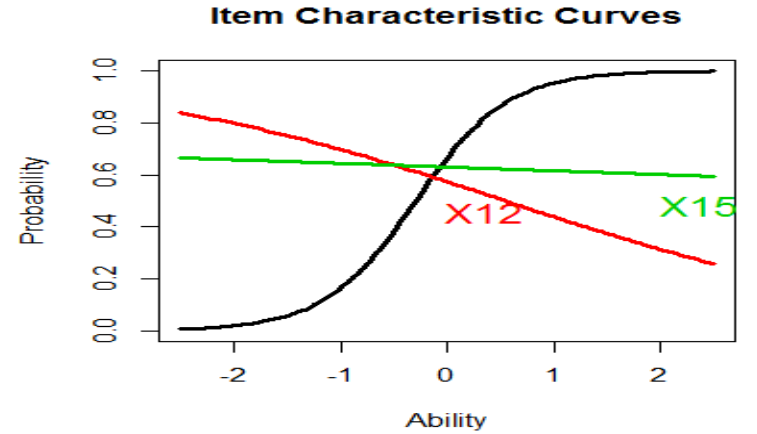

Gambar 3. Kurva Karakteristik Butir Soal Paket 01 Model 2P Berdasarkan Daya Beda

Gambar 3. Menunjukkan bahwa dari Paket 01 untuk butir 10, 12 dan 15 berada pada ketegori daya beda baik dan tidak baik. Berdasarkan grafik di atas butir 10 dengan koefisien $(2,336)$, butir $12(-0,541)$ dan butir $15(-0,062)$.

Gambar 4. Kurva Karakteristik Butir Soal Paket 02 Model 2P Berdasarkan Daya Beda

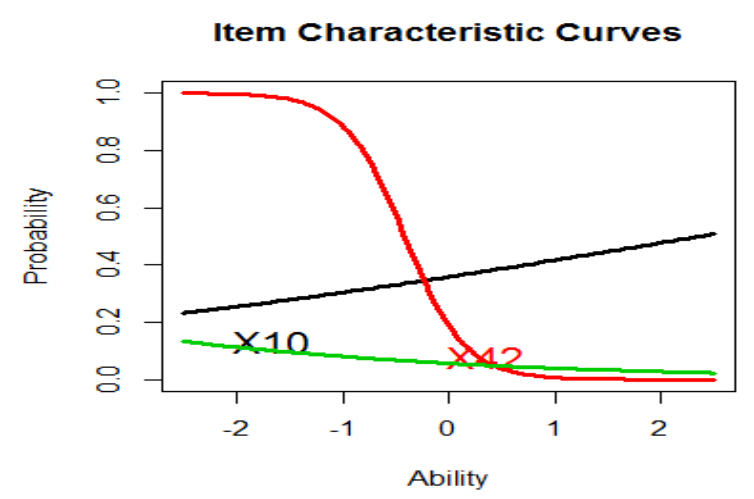

Gambar 4. Menunjukkan bahwa dari Paket 01 untuk butir 10, 12 dan 15 berada pada ketegori daya beda baik dan tidak baik. Berdasarkan grafik di atas butir 10 dengan koefisien $(0,246)$, butir $12(-3,517)$ dan butir $15(-0,376)$.

\section{Proses Penyetaraan}

Tabel 1. Hasil Analisis Penyetaran Paket 01 dan Paket 02 Berdasarkan Tingakt Kesulitan

\begin{tabular}{cccc}
\hline Item & $\begin{array}{c}\text { Tingkat } \\
\text { Kesulitan } \\
\text { Paket 01 }\end{array}$ & Item & $\begin{array}{c}\text { Tingkat } \\
\text { Kesulitan } \\
\text { Paket 02 }\end{array}$ \\
\hline X1 * & -1.2285 & X1 * & -1.2285 \\
X4 $*$ & -1.3191 & X4 $*$ & -1.3191 \\
X5 $*$ & 1.8568 & X5 * & 1.8568 \\
X9 $*$ & -0.0121 & X9 $*$ & -0.0121 \\
X11 $*$ & 1.76 & X11 * & 1.76 \\
\hline
\end{tabular}




\begin{tabular}{|c|c|c|c|}
\hline Item & $\begin{array}{l}\text { Tingkat } \\
\text { Kesulitan } \\
\text { Paket } 01\end{array}$ & Item & $\begin{array}{c}\text { Tingkat } \\
\text { Kesulitan } \\
\text { Paket } 02\end{array}$ \\
\hline $\mathrm{X} 13 *$ & -3.813 & X13* & -3.813 \\
\hline $\mathrm{X} 17 *$ & -2.6885 & $\mathrm{X} 17 *$ & -2.6885 \\
\hline X19* & -3.4957 & X19* & -3.4957 \\
\hline $\mathrm{X} 22 *$ & -64.7993 & $\mathrm{X} 22 *$ & -64.7993 \\
\hline $\mathrm{X} 23 *$ & 0.1564 & $\mathrm{X} 23 *$ & 0.1564 \\
\hline $\mathrm{X} 2$ & 0.792 & $\mathrm{X} 2$ & 49.0468 \\
\hline $\mathrm{X} 3$ & 0.8956 & X3 & -0.8029 \\
\hline X6 & -5.5107 & X6 & -7.968 \\
\hline X7 & 5.428 & X7 & -7.239 \\
\hline $\mathrm{X} 8$ & 21.0161 & $\mathrm{X} 8$ & -7.4211 \\
\hline X10 & 0.9299 & X10 & -1.3613 \\
\hline $\mathrm{X} 12$ & -1.3145 & X12 & -4.6144 \\
\hline X14 & -5.4764 & X14 & 2.7797 \\
\hline X15 & 2.9942 & X15 & -3.9942 \\
\hline X16 & -0.5261 & X16 & -2.949 \\
\hline X18 & -41.6036 & X18 & -2.1295 \\
\hline $\mathrm{X} 20$ & 3.5077 & X20 & -5.943 \\
\hline X21 & -16.6343 & X21 & -7.4089 \\
\hline X24 & 5.7664 & X24 & -3.7301 \\
\hline $\mathrm{X} 25$ & -1.1956 & X25 & -11.6686 \\
\hline X26 & 0.2582 & X26 & -0.8061 \\
\hline $\mathrm{X} 27$ & -1.78 & X27 & -3.647 \\
\hline $\mathrm{X} 28$ & -0.9063 & X28 & -11.9799 \\
\hline X29 & 0.9001 & X29 & -10.4849 \\
\hline X30 & 3.5058 & X30 & -15.8527 \\
\hline X31 & 0.5322 & X31 & -1.0979 \\
\hline X32 & -3.7073 & X32 & -5.0422 \\
\hline X33 & -0.2995 & X33 & -11.0177 \\
\hline X34 & -0.5566 & X34 & -2.3956 \\
\hline X35 & -2.3107 & X35 & -3.7131 \\
\hline X36 & -0.1692 & X36 & 15.7942 \\
\hline X37 & -2.3627 & X37 & 4.6689 \\
\hline X38 & 0.274 & X38 & -9.3939 \\
\hline X39 & -1.266 & X39 & -6.53 \\
\hline X40 & -1.0608 & X40 & -2.192 \\
\hline $\begin{array}{c}\text { Rata- } \\
\text { rata }\end{array}$ & -1.32934 & $\begin{array}{c}\text { Rata- } \\
\text { rata }\end{array}$ & -2.63645 \\
\hline
\end{tabular}

Tabel 2. Hasil Analisis Penyetaran Paket 01 dan Paket 02 Berdasarkan Daya Beda

\begin{tabular}{|c|c|c|c|}
\hline Item & $\begin{array}{c}\text { Daya } \\
\text { Pembeda } \\
\text { Paket } 01\end{array}$ & Item & $\begin{array}{c}\text { Daya } \\
\text { Pembeda } \\
\text { Paket } 02\end{array}$ \\
\hline $\mathrm{X} 1 *$ & 1.6519 & $\mathrm{X} 1 *$ & 1.6519 \\
\hline $\mathrm{X} 4 *$ & 1.031 & $\mathrm{X} 4 *$ & 1.031 \\
\hline $\mathrm{X} 5 *$ & 0.9785 & $\mathrm{X} 5 *$ & 0.9785 \\
\hline X9 * & 0.6023 & $\mathrm{X} 9 *$ & 0.6023 \\
\hline $\mathrm{X} 11 *$ & 0.7629 & $\mathrm{X} 11 *$ & 0.7629 \\
\hline $\mathrm{X} 13 *$ & 0.8504 & $\mathrm{X} 13 *$ & 0.8504 \\
\hline $\mathrm{X} 17 *$ & 1.3544 & $\mathrm{X} 17 *$ & 1.3544 \\
\hline X19* & 0.6776 & $\mathrm{X} 19 *$ & 0.6776 \\
\hline $\mathrm{X} 22 *$ & 0.0109 & $\mathrm{X} 22 *$ & 0.0109 \\
\hline $\mathrm{X} 23 *$ & 0.9352 & $\mathrm{X} 23 *$ & 0.9352 \\
\hline $\mathrm{X} 2$ & 1.0369 & $\mathrm{X} 2$ & -0.0268 \\
\hline X3 & -0.5462 & X3 & -2.0241 \\
\hline X6 & 0.617 & X6 & -0.4264 \\
\hline $\mathrm{X} 7$ & -0.5024 & $\mathrm{X} 7$ & -0.3418 \\
\hline $\mathrm{X} 8$ & -0.0257 & $\mathrm{X} 8$ & -0.3976 \\
\hline $\mathrm{X} 10$ & 1.1779 & $\mathrm{X} 10$ & -1.3373 \\
\hline $\mathrm{X} 12$ & 1.294 & $\mathrm{X} 12$ & 0.2483 \\
\hline $\mathrm{X} 14$ & 0.4065 & X14 & -0.4343 \\
\hline $\mathrm{X} 15$ & -0.3282 & $\mathrm{X} 15$ & 0.1475 \\
\hline X16 & 1.5127 & X16 & -0.9583 \\
\hline $\mathrm{X} 18$ & -0.0249 & $\mathrm{X} 18$ & 1.3471 \\
\hline $\mathrm{X} 20$ & -0.771 & $\mathrm{X} 20$ & -0.3643 \\
\hline $\mathrm{X} 21$ & 0.1022 & $\mathrm{X} 21$ & 0.2378 \\
\hline $\mathrm{X} 24$ & 0.1311 & $\mathrm{X} 24$ & -0.3165 \\
\hline $\mathrm{X} 25$ & -0.948 & $\mathrm{X} 25$ & -0.1613 \\
\hline X26 & -0.4544 & $\mathrm{X} 26$ & -0.9535 \\
\hline $\mathrm{X} 27$ & -2.3311 & $\mathrm{X} 27$ & -1.1006 \\
\hline $\mathrm{X} 28$ & -2.9037 & $\mathrm{X} 28$ & -0.1044 \\
\hline X29 & -1.7252 & X29 & 0.024 \\
\hline X30 & -2.5688 & X30 & -0.226 \\
\hline X31 & 0.669 & X31 & -1.1841 \\
\hline X32 & -0.333 & X32 & -0.3978 \\
\hline X33 & 1.6604 & X33 & -0.0461 \\
\hline X34 & -1.297 & X34 & -0.4061 \\
\hline X35 & -0.7037 & X35 & -0.6314 \\
\hline X36 & -0.3996 & X36 & 0.0748 \\
\hline X37 & -0.5643 & X37 & 0.3518 \\
\hline X38 & 1.0028 & X38 & -0.128 \\
\hline X39 & -2.3076 & X39 & -0.4294 \\
\hline X40 & 1.0751 & X40 & -1.3675 \\
\hline $\begin{array}{c}\text { Rata- } \\
\text { rata }\end{array}$ & -0.26831 & $\begin{array}{c}\text { Rata- } \\
\text { rata }\end{array}$ & -0.37774 \\
\hline
\end{tabular}

* = Anchor Item (Butir yang sama dari kedua perangkat)

Berdasarkan hasil pengolahan data Tabel 2 . Menunjukan bahwa paket 01 dan paket 02 ditinjau dari daya beda, bahwa kedua paket soal tidak mampu membedakan antara kemampuan 
peserta dengan kemampuan tinggi dan kemampuan rendah. Berdasarkan rata-rata daya beda paket $01(-0.26831)$ dan rata-rata paket 02 $(-0.37774)$.

\section{SIMPULAN DAN SARAN}

Berdasarkan hasil analisis dan pembahasan sebelumnya dapat disimpulkan bahwa Kualitas soal paket 01 Tes Potensi Akademik berdasarkan tingkat kesulitan terdapat 23 butir kategori baik dan paket 02 terdapat 10 butir kategori baik. Sedangkan Kualitas soal paket 01 Tes Potensi Akademik berdasarkan daya beda terdapat 22 butir kategori baik dan paket 02 terdapat 17 butir kategori baik.

Prosedur penyetaraan tes, tahap pertama pemilihan jenis penyetaraan horizontal,kedua pemilihan desain penyetaraan Common-Item Nonequivalent, ketiga dilanjutkan dengan estimasi parameter dengan menggunakan model 2 parameter (daya beda dan tingkat kesulitan) dan keempat dilakukan proses penyetaraan dengan menggunakan testEquatingData.

Penyetaraan tes dengan Metode tesEquatingData berdasarkan teori respon butir menggunakan model 2 parameter, menunjukkan bahwa rata-rata tingkat kesulitan pada kedua paket berbeda dengan nilai paket 01 (-1.32934) dan nilai paket 02 (-2.63645). Sedangkan ditinjau dari daya beda kedua paket juga berbeda dan menunjukkan bahwa tidak dapat membedakan kemampuan peserta, antara kemampuan tinggi dengan kemampuan peserta rendah, berdasarkan nilai paket $01(-0.26831)$ dan paket 02 (-0.37774).

\section{SARAN}

Untuk penelitian selanjutnya disarankan dengan penyetaraan tes dengan beberapa metode penyetaraan dan model paramater yang bebeda dengan subyek yang sama dengan dengan tes yang berbeda. Selanjutnya dengan Melakukan penyetaraan tes, sudah seharusnya dilakukan oleh perguruan tinggi swasta, dengan upaya itu, setelah beberapa tahun baik dosen ataupun perguruan tinggi, memilki bank tes yang setara.

\section{DAFTAR PUSTAKA}

Aminah, N. S. (2012). Karakteristik metode penyetaraan skor tes untuk data dikotomos. Jurnal Penelitian Dan Evaluasi Pendidikan, 16, 88-101.

Antara, A. A. P., \& Bastari. (2015). Penyetaraan Vertikal Dengan Pendekatan Klasik Dan Item Response Theory Pada Siswa Sekolah Dasar, 19(1), 13-24
Bintarawati, D. (2012). The accuracy of concordance method. Jurnal Evaluasi Pendidikan, 3(2), 107-117. Retrieved from http://journal.unj.ac.id/unj/index.php/jep /article/download/2683/2032

Daeng, K. (2015). Pengembangan materi pembelajaran makassar bagi siswa SMP/MTS. di sulawesi selatan Journal of Educational Science and Technology, 1, 27-38.

Inteni, K. A. S., Candiasa, I. M., \& Suarni, N. K. (2013). Pengembangan Instrumen Tes Objektif Pilihan Ganda Yang Diperluas Berbasis Web Untuk Mata Pelajaran Tik Kelas $\mathrm{Xi}$ Sman Di Kabupaten Karangasem. E-Journal Program Pascasarjana Universitas Pendidikan Ganesha Program Studi Penelitian Dan Evaluasi Pendidikan, 3(5).

Miyatun, E., \& Mardapi, D. (2000). Komparasi Metode Penyetaraan Tes Menurut Teori Respon Butir. Jurnal Penelitian dan Evaluasi UNY (online).Nomor 3, Tahun II. 2000

Mardapi, Djemari. (2012). Pengukuran Penilaian \& Evaluasi

Pendidikan.Yogyakarta. PT. Nuha Litera.

Mistiani, W. (2015). Keadilan gender dalam penilaian hasil belajar. Musawa, 7(2), 283-302.

Permatasari, T. O., Prabandari, Y. S., \& Kristina, T. N. (2016). Faktor Kognitif dan Non-Kognitif Pada Seleksi Mahasiswa Baru Sebagai Prediktor Terhadap Prestasi Akademik. Jurnal Penelitian Dan Evaluasi Pendidikan, 20(1).

Ruslan. 2005. Penyetaraan Kemampuan Peserta Tes. Jurnal Pendidikan Matematika dan Matematika UNM. Vol. 5, No 2

Tumilisar, A. J. V.2006. Akurasi Relatif Penyetaraan Skor Tes untuk Sampel Berukuran 300 Ditinjau dari Metode Penyetaraan dan Teknik Penghalusan. Jurnal Pendidikan Penabur. No.06/Th.V/Juni 2006

Tamsyani, W. (2016). Pengaruh Model Pembelajaran dan Kesadaran Metakognitif. Journal of Educational Science and Technology, 2(1), 10-26.

Syaifuddin, Mohammad. 2005. Penyetaraan Tes Model Respons Berjenjang. Disertasi. 
Tidak diterbitkan. Program Pascasarjana Univeritas Negeri Yogyakarta. 